\title{
HUBUNGAN KEPERCAYAAN KESEHATAN DENGAN KEPATUHAN MINUM OBAT PADA PENDERITA DIABETES MELLITUS TIPE 2
}

\author{
Istianna Nurhidayati $^{1)}$, Fitri Suciana ${ }^{2)}$, Ida Zulcharim ${ }^{3)}$ \\ ${ }^{1,2)}$ Program Studi Sarjana Keperawatan Stikes Muhammadiyah Klaten \\ Jl. Jombor Indah, Gemolong, Buntalan, Kec. Klaten Tengah, Kabupaten Klaten, Jawa Tengah 57419 \\ istiannanurhidayati@gmail.com
}

\begin{abstract}
Abstrak
Penyakit diabetes mellitus di Kabupaten Klaten mengalami peningkatan khususnya di Puskesmas Karangnongko. Pada tahun 2016 terdapat $15(0,002 \%)$ penderita dan tahun 2017 sebanyak $538(0,05 \%)$. Tujuan penelitian ini mengetahui hubungan kepercayaan kesehatan dengan kepatuhan minum obat pada penderita diabetes mellitus tipe 2 di Puskesmas Karangnongko.

Penelitian ini menggunakan desain deskriptif analitik dengan pendekatan cross sectional. Sampel sebanyak 44 responden, diperoleh dengan teknik purposive sampling. Instrumen pengumpulan data menggunakan kuesioner. Analisa data bivariat menggunakan uji pearson correlation.

Hasil penelitian menunjukkan rata-rata usia responden 53 tahun usia paling muda 40 tahun dan paling tua 63 tahun, jenis kelamin responden perempuan (75,0\%), tingkat pendidikan SD (50,0\%), tidak bekerja (56,8\%), lama menderita diabetes mellitus $<5$ tahun $(75,0 \%)$, gula darah puasa $>126 \mathrm{mg} / \mathrm{dl}(88,6 \%)$, masalah kesehatan lain yang dirasakan ada $(61,4 \%)$, obat yang dikonsumsi biguanide (79,5\%). Kepercayaan kesehatan pada penelitian ini minimal 65 , maksimal 141 dan ratarata 112.66 \pm 21.824 . Kepatuhan minum obat minimal 3, maksimal 8 dan rata-rata 6.34 \pm 1.413 . Hasil uji Pearson correlation menunjukkan ada hubungan kepercayaan kesehatan dengan kepatuhan minum obat $(\mathrm{p}=0,000)$. Hubungan kepercayaan kesehatan dengan kepatuhan minum obat menunjukkan korelasi positif yang sedang dengan nilai koefisien korelasi atau nilai $r=0.489$. Kepercayaan kesehatan memiliki hubungan dengan kepatuhan minum obat penderita diabetes mellitus tipe 2 di Puskesmas Karangnongko.
\end{abstract}

Kata Kunci: Kepercayaan kesehatan, kepatuhan minum obat, diabetes mellitus tipe 2

\begin{abstract}
Diabetes mellitus in Klaten have increased, especially in Karangnongko health center in 2016 there were 15 (0.002\%) patients and in 2017 there were $538(0.05 \%)$. This study aimed to determine relationship of health beliefs with medication adherence in patients with type 2 diabetes mellitus in the Karangnongko health center. This research used descriptive analytic design with cross sectional approach. Sample this study was 44 respondents, obtained by purposive sampling technique. The instruments of data collection used questionnaires. The results of the Pearson correlation analysis concluded average age of respondents was 53 years, the youngest age was 40 years and the oldest was 63 years, the sex of female respondents (75.0\%), education level of elementary school (50.0\%), not working (56.8\%), duration of diabetes mellitus $<5$ years (75.0\%), fasting blood sugar $>126 \mathrm{mg} / \mathrm{dl}(88.6 \%)$, other perceived health problems $(61.4 \%)$, drugs consumed biguanide (79.5\%). Health belief in this study at least 65, a maximum of 141 and an average of 112.66 $\pm 21,824$. Medication adherence at least 3 , a maximum of 8 and an average of $6.34 \pm 1,413$. Pearson correlation test results was a relationship of health belief with medication adherence $(p=0,000)$. Relation of health belief with medication compliance showed a moderate positive correlation with correlation coefficient value or $r=0.489$ which means the greater the confidence of health hence the higher compliance of drug in diabetes mellitus type 2 at Karangnongko Health Center. Health belief have a relationship with the adherence of taking drugs diabetes mellitus type 2 at Karangnongko Health Center.
\end{abstract}

Keywords: Health belief, diabetes mellitus type 2, medication adherence.

\section{Pendahuluan}

Diabetes militus merupakan penyakit kronis tidak menular yang ditandai dengan meningkatnya kadar gula dalam darah melebihi normal. Data studi global, pada tahun 2013 dilaporkan lebih dari 21 juta kelahiran dipengaruhi oleh diabetes selama hamil. Diabetes juga telah menyebabkan 5,1 juta kematian. Pada tahun 2013 sebanyak 382 juta orang telah terkena penyakit diabetes, dan diperkirakan akan meningkat menjadi 592 juta pada tahun 2035 dengan peningkatan paling tinggi adalah diabetes millitus tipe 2 .

Penyakit DM merupakan salah satu masalah kesehatan masyarakat yang serius dihadapi dunia, termasuk negara berkembang yaitu Indonesia (WHO, 
2010). Indonesia menempati urutan ke tujuh di dunia untuk negara dengan penderita diabetes terbanyak setelah China, India, Amerika, Brazil, Rusia dan Mexico (International Diabetes Federation, 2013). Prevalensi DM berdasarkan diagnosis dokter tertinggi terdapat di Yogyakarta (2,6\%), DKI Jakarta (2,5\%), Sulawesi Utara (2,4\%), dan Kalimantan Timur (2,3\%). Prevalensi DM tertinggi umur 55-64 (4,8\%), jenis kelamin laki-laki $(1,7 \%)$, pendidikan tamat D1-D3/PT $(2,5 \%)$, status pekerjaan wiraswasta $(2,0 \%)$, tempat tinggal diperkotaan $(2,0 \%)$, kuintil indeks kepemilikan teratas (2,6\%) (Riskesdas, 2013, h90). Di daerah Jawa Tengah terjadi peningkatan penderita DM.

Data Dinas Kesehatan Jawa Tengah pada tahun 2012 menunjukkan prevalensi DM sebesar 0,06\% lebih rendah dibandingkan tahun $2011(0,09 \%)$. Prevalensi tertinggi adalah Kabupaten Semarang sebesar 0,66\%. Sedangkan prevalensi DM tipe II telah mengalami penurunan dari 0,63\% menjadi 0,55\% pada tahun 2012 . Prevalensi tertinggi adalah kota Magelang sebesar 7,93\% (Dinkes Jateng, 2012). Hasil Riskesdas (2013) menunjukkan prevalensi DM mengalami peningkatan pada tahun 2007 sebesar $1,1 \%$ menjadi $2,1 \%$ pada tahun 2013. Pada tahun 2013, prevalensi terbanyak terdapat di kota Surakarta dan Salatiga sebesar 2,21\%. Berdasarkan data kasus penyakit tidak menular di Jawa Tengah yang dimuat dalam Buku Profil Kesehatan Jawa Tengah tahun 2012, Kota Surakarta menempati peringkat pertama kota dengan jumlah kasus diabetes tipe 2 terbanyak di Provinsi Jawa Tengah. Proporsi kasus diabetes mellitus pada tahun 2015 sebesar (18,33\%) dari 5 kasus penyakit tidak menular di Jawa Tengah (Dinkes Prov , 2015, h46).

Di Kabupaten Klaten terjadi peningkatan penderita DM. Kabupaten Klaten menempati urutan ke5 dengan jumlah kasus diabetes tipe 2 sebanyak $(0,89 \%)$ di tahun 2012 (Depkes RI, 2012). Diabetes mellitus termasuk 5 besar penyakit tidak menular di Kabupaten Klaten. Tahun 2014 sebesar $(0,87 \%)$ dan tahun 2015 sebesar (0,72\%) (Profil Kesehatan Kabupaten Klaten, 2015, h34). Data dari Dinas Kesehatan Kabupaten Klaten tahun 2016 menunjukkan terdapat 1270 (0,10\%) yang menderita diabetes mellitus. pada tahun 2017 mengalami peningkatan dari $1270(0,10 \%)$ menjadi $12214(1,05 \%)$ yang menderita penyakit diabetes mellitus tipe 2. Di Puskesmas Karangnongko pada tahun 2016 terdapat $15(0,002 \%)$ yang menderita penyakit diabetes mellitus tipe 2 dan pada tahun 2017 mengalami peningkatan yang drastis sebanyak 538 $(0,05 \%)$ yang menderita penyakit diabetes mellitus tipe 2 (Dinkes Klaten, 2017).

Faktor penyebab terjadinya diabetes mellitus tipe 2 antara lain usia, obesitas, Makanan, aktivitas fisik, gaya hidup (Betteng, Pangemanan, \& Mulyani, 2014, h402) . Faktor tersebut didukung hasil penelitian Wicaksono (2011) menyimpulkan ada hubungan antara
Usia >45 tahun, inaktivitas, dan riwayat keluarga terhadap terjadinya diabetes mellitus. Sejalan dengan penelitian tersebut, Prasetyani dan Sodikin (2017) menyimpulkan adanya hubungan signifikan antara jenis kelamin dan obesitas dengan kejadian DM tipe 2. Didukung oleh hasil penelitian yang dilakukan Wahyuni (2010) dengan hasil ada hubungan antara umur, jenis kelamin, pekerjaan, obesitas, hipertensi, konsumsi lemak, merokok, konsumsi alkohol, dan konsumsi kafein berhubungan dengan penyakit diabetes mellitus.

Komplikasi pada DM meliputi komplikasi akut dan komplikasi kronik. Komplikasi akut DM diantaranya hipoglikemia, diabetic ketoacidosis (DKA), Hiperosmolar hyperglycemic nonketocic syndrome (HHNS) dan komplikasi kronik meliputi makroangiopati, mikroangiopati, penyakit neuropatik (Brunner \& Suddarth, 2013, h212). Teori Brunner \& Suddarth tersebut didukung hasil penelitian Purwanti dan Maghfirah (2016) yang menyimpulkan ada pengaruh gangguan penglihatan terhadap kejadian komplikasi kronik (kaki diabetik) pada pasien DM tipe 2. Dan didukung hasil penelitian yang dilakukan Anggraheny, Setyoko dan Septikusuma (2012) juga mendukung teori tersebut,yaitu ada hubungan antara kejadian diabetes mellitus tipe 2 dengan penyakit jantung iskemik. Komplikasi DM dapat dilakukan pengendalian dan pencegahan dengan mengelola DM.

Pengelolaan diabetes militus dikenal dengan 5 pilar yaitu edukasi, terapi gizi, latihan jasmani dan terapi farmakologi, monitoring gula darah (Perkeni, 2011). Apabila pengelolaan tidak dilakukan dengan baik maka penderita diabetes militus beresiko lebih mudah terkena komplikasi. Latihan jasmani yang dipaparkan oleh Perkeni sejalan dengan penelitian yang dilakukan oleh Rachmawati (2010) menyimpulkan ada hubungan latihan jasmani dengan kadar glukosa darah penderita DM tipe 2.Faktor yang berperan dalam mengontrol kadar gula dalam darah pada penderita Diabetes millitus (DM) yaitu kepatuhan penderita secara farmakologis dengan mengkonsumsi obat penurun gula darah. Kepatuhan adalah sejauh mana perilaku individu (misalnya, minum obat, mematuhi diet, atau melakukan perubahan gaya hidup) sesuai anjuran terapi atau kesehatan (Potter \& pery, 2010).

Penderita diabetes militus harus memiliki kemampuan untuk mengontrol penyakitnya dengan minum obat yang ditentukan dari kemampuan penderita diabetes militus memahami persepsi kepercayaan kesehatan. Kepercayaan kesehatan merupakan suatu konsep hasil persepsi atau keyakinan individu untuk menjelaskan dan memprediksi seseorang mengambil tindakan dalam pencegahan, deteksi dini, atau mengontrol penyakit akut maupun kronis (Glanz, Rimer, Viswanath, 2008, h47-h50). Persepsi positif tentang penyakit yaitu seseorang dapat memahami penyakit dengan cara untuk mengontrol penyakitnya 
dengan baik, akan tetapi nila sebaliknya persepsi negatif tentang penyakit yaitu seseorang tidak dapat dengan baik memahami penyakit dan cara yang tepat untuk mengontrol penyakitnya.

Komponen dari konsep kepercayaan kesehatan yang dapat menjelaskan ketidakpatuhan penderita diabetes militus yaitu kerentanan yang dirasakan konstruk dengan resiko atau kerentanan (perceived susceptibily), keseriusan yang dirasa (perceived severity), manfaat yang dirasakan (perceived benefit) dan hambatan yang dirasakan untuk berubah (perceived barriers), perilaku yang dipengaruhi (cues to action), Kepercayaan diri (Self efficacy) (Priyoto, 2014, h136138). Hal ini sesuai dengan penelitian yang dilakukan Ulum, Kusnanto, dan Widyawati (2014) tentang kepatuhan penderita diabetes militus berdasarkan teori kepercayaan kesehatan, menyatakan yang paling dominan dengan kepatuhan penderita diabetes militus tipe 2 adalah persepsi keseriusan. Berdasarkan latar belakang dan fenomena tersebut penelitian ini bertujuan mengetahui hubungan kepercayaan kesehatan dengan kepatuhan minum obat penderita diabetes mellitus tipe 2 di puskesmas Karangnongko.

Metode

Penelitian ini merupakan penelitian kuantitatif non eksperimental yang mempunyai rancangan deskriptif analitik dengan pendekatan cross sectional. Populasi penelitian ini sebanyak 76 responden dan sampel sebanyak 44 responden yang diperoleh dengan teknik purposive sampling. Reponden adalah yang memenuhi kriteria inklusi dan eksklusi penelitian yaitu usia $>30$ th, memperoleh resep obat antidiabetes, pendidikan minimal SD, didiagnosa medis DM tipe 2, bersedia menjadi responden. Penelitian ini dilakukan di puskesmas Karangnongko dan pengambilan data selama 2 hari pada tanggal 9 Mei 2018 dan 14 Mei 2018. Penelitian ini menggunakan kuesioner kepercayaan kesehatan yang dibuat oleh peneliti dan sudah diuji validitas di puskesmas kemalang dan kuesioner $M M A S$ 8. Variabel dalam penelitian ini kepercayaan kesehatan yang dibuat sendiri oleh peneliti. kuesioner kepatuhan minum obat menggunakan MMAS-8 telah dsitasi oleh Arifin (2016) dan peneliti telah mendapatkan ijin untuk menggunakan kuesioner dari arifin melalui Gmail.

Hasil

\section{A. Distribusi responden}

Tabel 1. Rata-rata usia responden penderita diabetes mellitus tipe 2 di Puskesmas Karangnongko tahun 2018 $(\mathrm{n}=44)$

\begin{tabular}{ccccc}
\hline \multirow{3}{*}{ Usia } & \multicolumn{4}{c}{ Usia Responden } \\
\cline { 2 - 5 } & Minimum & Maksimum & Mean & Sd \\
\cline { 2 - 5 } & 40 & 63 & 53,30 & 6,663 \\
\hline
\end{tabular}

Tabel 2. Distribusi Frekuensi Karakteristik Responden Berdasarkan Jenis Kelamin, Pendidikan, Pekerjaan, Lama menderita diabetes mellitus, Gula darah puasa, Masalah kesehatan lain yang dirasakan, Obat yang dikonsumsi di Puskesmas Karangnongko Tahun 2018 $(\mathrm{n}=44)$

\begin{tabular}{|c|c|c|c|}
\hline No & Karakteristik & Frekuensi & $\%$ \\
\hline & Jenis Kelamin & & \\
\hline 1 & Laki-laki & 11 & 25,0 \\
\hline \multirow[t]{3}{*}{2} & Perempuan & 33 & 75,0 \\
\hline & Total & 44 & 100 \\
\hline & Pendidikan & & \\
\hline 1 & $\mathrm{SD}$ & 22 & 50,0 \\
\hline 2 & SMP & 16 & 36,4 \\
\hline 3 & SMA/SMK & 5 & 11,4 \\
\hline \multirow[t]{3}{*}{4} & Perguruan Tinggi & 1 & 2,3 \\
\hline & Total & 44 & 100 \\
\hline & Pekerjaan & & \\
\hline 1 & Bekerja & 19 & 43,2 \\
\hline \multirow[t]{3}{*}{2} & Tidak bekerja & 25 & 564 \\
\hline & Total & 44 & 100 \\
\hline & Lama menderita DM & & \\
\hline 1 & $<5$ Tahun & 33 & 75,0 \\
\hline 2 & 5-10 Tahun & 9 & 20,5 \\
\hline \multirow[t]{3}{*}{3} & $>10$ Tahun & 2 & 56,8 \\
\hline & Total & 44 & 100 \\
\hline & Gula darah puasa & & \\
\hline 1 & $72-126 \mathrm{mg} / \mathrm{dl}$ & 5 & 11,4 \\
\hline \multirow[t]{3}{*}{2} & $>126 \mathrm{mg} / \mathrm{dl}$ & 39 & 88,6 \\
\hline & Total & 44 & 100 \\
\hline & $\begin{array}{l}\text { Masalah kes lain yg } \\
\text { dirasakan }\end{array}$ & & \\
\hline 1 & Ada & 27 & 61,4 \\
\hline \multirow[t]{3}{*}{2} & Tidak ada & 17 & 38,6 \\
\hline & Total & 44 & 100 \\
\hline & Obat yg dikonsumsi & & \\
\hline 1 & Sulfunilera & 9 & 20,5 \\
\hline \multirow[t]{2}{*}{2} & Biguanide & 35 & 79.5 \\
\hline & Total & 44 & 100 \\
\hline
\end{tabular}

Tabel 3. Rata-rata Kepercayaan kesehatan dan kepatuhan minum obat Penderita diabetes mellitus tipe 2 di Puskesmas Karangnongko $2018(n=44)$

N Min Max Mean $\begin{array}{ll}\text { Std. } \\ \text { Deviasi }\end{array}$

\begin{tabular}{lccccc}
\hline $\begin{array}{l}\text { Kepercayaa } \\
\mathrm{n} \text { kesehatan }\end{array}$ & 44 & 65 & 141 & 112.66 & 21.824 \\
\hline $\begin{array}{l}\text { Kepatuhan } \\
\text { Minum }\end{array}$ & 44 & 3 & 8 & 6.34 & 1.413 \\
Obat & & & & & \\
\hline
\end{tabular}




\section{B. Hubungan kepercayaan kesehatan dengan kepatuhan Minum Obat}

Tabel 6. Hasil Analisis Hubungan Kepercayaan Kesehatan dengan Kepatuhan Minum Obat Penderita Diabetes Mellitus tipe 2 di Puskesmas Karangnongko Tahun $2018(n=44)$

\begin{tabular}{llll}
\hline & $\mathrm{N}$ & $\begin{array}{l}\text { Sig. }(2- \\
\text { tailed) }\end{array}$ & $\begin{array}{l}\text { Pearson } \\
\text { Correlation }\end{array}$ \\
\hline $\begin{array}{l}\text { Kepercayaan } \\
\text { kesehatan }\end{array}$ & 44 & .000 & $489^{* *}$ \\
\hline $\begin{array}{l}\text { Kepatuhan } \\
\text { Minum Obat }\end{array}$ & 44 & .000 & $489^{* *}$ \\
\hline
\end{tabular}

Tabel 6. diatas menunjukkan terdapat hubungan antara kepercayaan kesehatan dengan kepatuhan minum obat penderita diabetes mellitus tipe 2 di Puskesmas Karangnongko. Dengan nilai p value 0,000 atau nilai $\mathrm{p}$ value $<0,05$. Hubungan kepercayaan kesehatan dengan kepatuhan minum obat menunjukkan korelasi positif yang sedang dengan nilai koefisien korelasi atau nilai $r=489$ yang berarti semakin besar kepercayaan kesehatan maka semakin tinggi kepatuhan minum obat pada penderita diabetes mellitus tipe 2 di Puskesmas Karangnongko.

\section{Pembahasan}

Hasil penelitian menunjukkan dari 44 responden memiliki rata-rata usia 53,30 tahun dengan standar deviasi $\pm 6,663$. Usia responden paling paling muda 40 dan yang paling tua 63 tahun. Hasil penelitian ini didukung oleh Ulum, Kusnanto dan Widyawati (2014) yang menunjukkan rata-rata responden penderita DM berusia 53 tahun. Penelitian Hasbi (2017) juga menunjukkan bahwa rerata usia reponden adalah 57 tahun atau termasuk kategori usia dewasa pertengahan (Kozier \& Erb's, 2012). Notoadmojo (2013) menyatakan usia memiliki hubungan derajat tingkat keterpaparan, besarnya resiko serta resistensi terhadap penyakit. Sejalan dengan hasil riskesdas (2018) menemukan di Indonesia usia terbanyak menderita DM adalah usia dewasa tengah (6,3\%). Betteng, Pangemanan \& Mayulu (2014) menjelaskan seseorang $\geq 45$ tahun memiliki peningkatan resiko terhadap terjadinya DM dan intoleransi glukosa yang di sebabkan oleh faktor degenerative yaitu menurunnya fungsi tubuh, khususnya kemampuan dari sel $\beta$ dalam memproduksi insulin untuk metabolisme glukosa. Selain itu sel tubuh yang menjadi reseptor insulin menjadi tidak peka terhadap insulin sehingga insulin tidak dapat bekerja dengan optimal.

Hasil penelitian menunjukkan mayoritas jumlah responden prolanis dan posbindu berdasarkan jenis kelamin terbanyak adalah perempuan 33 responden $(75,0 \%)$. Hal ini sejalan dengan penelitian yang dilakukan Purwanti \& Nurhayati (2017) menunjukkan mayoritas jumlah responden berjenis kelamin perempuan yaitu 46 orang $(51,9 \%)$. Dan didukung oleh hasil penelitian Ulum, Kusnanto dan Widyawati (2014) menunjukkan proporsi responden berdasarkan jenis kelamin terbanyak adalah perempuan. Novian (2013) memaparkan jenis kelamin berkaitan dengan dengan peran kehidupan dan perilaku yang berbeda antara lakilaki dan perempuan dalam masyarakat. Dalam menjaga kesehatan biasanya kaum perempuan lebih memprioritaskan kesehatannya dibanding laki-laki. Temuan penelitian ini sejalan dengan hasil Riskesdas (2018) dimana penderita diabetes mellitus yang ditegakkan dokter lebih banyak perempuan dibandingkan dengan laki-laki.

Hasil penelitian menunjukkan sebagian besar responden berpendidikan SD yaitu 22 responden $(50,0 \%)$. Hasil penelitian ini sesuai dengan penelitian Setyorogo dan Trisnawati (2013) tentang faktor resiko kejadian DM tipe 2 di Puskesmas Kecamatan Cengkareng Jakarta Barat tahun 2012 menunjukkan pendidikan sebagian besar responden adalah berpendidikan rendah yaitu SD dan SMP. Irawan (2010) menyatakan tingkat pendidikan memiliki pengaruh terhadap kejadian diabetes mellitus tipe 2 . Notoadmodjo (2005) menjelaskan pendidikan merupakan hal yang sangat penting, karena semakin tinggi tingkat pendidikan, semakin besar memiliki banyak pengetahuan dan teknologi yang berdampak pada peningkatan kesejahteraan seseorang.

Sebagian besar responden tidak bekerja yaitu 25 responden $(56,8 \%)$ dan yang bekerja 19 responden $(43,2 \%)$. Hasil penelitian ini didukung oleh Arifin (2012) menunjukkan bahwa responden yang tidak bekerja beresiko 1,6 kali mengalami komplikasi dibanding responden yang bekerja. Hal ini dikaitkan dengan aktivitas yang dilakukan penderita dalam kehidupan sehari-hari. Aktivitas yang dilakukan oleh penderita diabetes mellitus meningkatkan penggunaan energi di dalam tubuh manusia sehingga mampu menurunkan kadar glukosa darah. Aktivitas yang dilakukan responden adalah senam seminggu sekali yang dilaksanakan pada hari Rabu di Puskesmas Karangnongko. Mubarok (2007) mengemukakan bahwa pekerjaan menjadi salah satu faktor yang dapat yang dapat mempengaruhi pengetahuan, dimana lingkungan pekerjaan dapat menjadikan seseorang memperoleh pengalaman dan pengetahuan yang baik secara langsung maupun tidak langsung.

Sebagian besar responden lama menderita diabetes mellitus $<5$ tahun yaitu 33 responden $(75 \%)$. Hasil penelitian ini sejalan dengan penelitian Ulum, Kusnanto, Widyawati (2014) menunjukkan bahwa mayoritas responden menderita penyakit DM tipe 2 lebih dari sama dengan 6 bulan. Hal ini juga didukung dengan penelitian Purwanti dan Nurhayati (2017) menunjukkan terdapat 76 responden $(98,7 \%)$ menderita DM lebih dari 6 bulan. Semakin lama penderita menderita DM dengan hiperglikemia maka akan 
semakin tinggi kemungkinan terjadinya komplikasi kronik karena adanya kadar glukosa darah yang abnormal dan semakin lama menderita diabetes mellitus maka semakin bosan dan tidak patuh dalam minum obat (Waspadji, 2009).

Lama menderita diabetes mellitus yang terlalu lama (>10 tahun) menimbulkan penderita untuk mengkombinasi antara obat antidiabetes dengan obat herbal. Hal-hal yang melatarbelakangi penderita memilih 2 pilihan adalah pengalaman seseorang dan cerita dari teman ke teman. Hasil penelitian Rahmawati dan Fitriani (2016) menunjukkan bahwa pasien diabetes mellitus menggunakan obat herbal diabetes sebanyak $60,32 \%$ bersamaan dengan obat antidiabetes. Berdasarkan hasil penelitian terdapat jenis tanaman brotowali 2,63\% mayoritas mengkonsumsi antidiabetes herbal yang diolah sendiri melalui proses perebusan yang bahannya mereka cari sendiri dengan membeli dipasar atau mendapatkan dari pohon sekitar rumah dan tetangga.

Penyakit diabetes mellitus sering kali terdiagnosa pada saat telah mengalami komplikasi, padahal proses perjalanan penyakit telah terjadi bertahun-tahun sebelumnya. Hal ini dibuktikan bahwa lebih banyak yang mengalami masalah kesehatan lain yang dirasakan ada (mata kabur, hipertensi serta nyeri dan kebas pada kaki) ada 27 responden (61,4\%). Dan mayoritas menggunakan obat biguanide 35 responden $(79,5 \%)$.

Hasil penelitian menunjukkan gula darah puasa $>126 \mathrm{mg} / \mathrm{dl}$ yaitu 39 responden $(88,6 \%)$. Hal ini sejalan dengan penelitian Nurayati dan Adriani (2017) menjelaskan bahwa kadar glukosa darah puasa responden penderita diabetes mellitus tipe 2 di wilayah kerja Puskesmas Mulyorejo kota Surabaya sebagian responden memiliki kadar gula darah puasa yang tinggi yaitu lebih dari $126 \mathrm{mg} / \mathrm{dl}$ sebanyak 33 orang dengan persentase 58,0\% dengan \pm SD 47,19.

Hiperglikemia secara anamnesis ditemukan adanya masukan kalori yang berlebihan, penghentian obat oral maupun insulin yang didahului stress akut. Penderita menderita hiperglikemia dan glukosuria berat, penurunan hipogenesis, peningktan lipolisis, dan peningkatan oksidasi asam lemak bebas disertai pembentukan benda keton. Peningkatan keton dalam plasma menyebabkanketosis dengan tanda khas penurunan kesadaran disertai dehidrasi berat. Jika keluhan khas kadar glukosa darah sewaktu $>126 \mathrm{mg} / \mathrm{dl}$, gula darah sewaktu $>200 \mathrm{mg} / \mathrm{dl}$, sudah cukup untuk menegakkan diagnosis DM (Smltzer \& Bare, 2012)

Hasil penelitian menunjukan masalah kesehatan lain yang dirasakan ada 27 responden (61,4\%). Masalah kesehatan lain yang dirasakan merupakan penyakit yang serius. Komplikasi dapat dikategorikan kedalam komplikasi metabolisme akut yang terjadi akibat perubahan yang relative akut dari kadar glukosa plasma. Kategori lain adalah komplikasi vaaskuler yang akan mengakibatkan kerusakan fungsi bagian tubuh yang terkena (IDF,2013). Komplikasi yang diperoleh dari responden hipertensi, pandangan kabur, nyeri dan rasa kebas pada kaki.

Sebesar 35 responden $(79,5 \%)$ mengkonsumsi obat biguanide. Golongan biguanide yaitu metformin, metformin merupakan obat yang dapat menurunkan resistensi insulin dan juga mempengaruhi produksi glukosa hati. PERKENI (2011) memaparkan metformin merupakan pilihan pertama pada sebagian besar kasus DM tipe 2. Metformin dapat menurunkan kadar glukosa darah yang tinggi, metformin bekerja dengan cara menghambat proses glukoneogenesis dan glikogeneolisis, memperlambat penyerapan glukosa pada usus, serta meningkatkan sensitifitas insulin dalam tubuh (PERKENI,2015).

Metformin sering digunakan oleh penderita DM karena terapi metformin jarang memberikan efek hipoglikemia, dan metformin dapat digunakan secara aman tanpa menyebabkan hipoglikemia pada prediabetes. Efek nonglikemik yang penting dari metformin adalah tidak menyebabkan penambahan berat badan atau menyebabkan penurunan berat badan sedikit (Arifin, 2012).

Hasil penelitian kepercayaan kesehatan menunjukkan dari 44 responden di Puskesmas Karangnongko menunjukkan bahwa hasil rata-rata hasil jawaban kuesioner pada penelitian ini 112.66 \pm 21.824 dengan hasil minimal 65 dan maksimal 141. Hal ini sejalan dengan penelitian yang dilakukan oleh Hasbi (2017) menunjukkan bahwa responden mempunyai persepsi kerentanan baik $(54,1 \%)$, persepsi keseriusan baik $(51,6 \%)$, persepsi manfaat $(53,3 \%)$, hambatan baik (54\%).

Hasil penelitian kepatuhan minum obat menunjukkan bahwa rerata kepatuhan minum obat $6.34 \pm 1.413$ dengan kepatuhan obat minimal 3 dan maksimal 8. Hal ini sejalan dengan penelitian yang dilakukan Adikusuma dan Qiyaam (2017) menunjukkan pasien patuh $50 \%$ dan patuh $50 \%$. Serta adanya korelasi negatif antara kepatuhan. pengobatan pasien DMT2 terhadap kadar HbAlc $(r=0,081, p=0,619)$ berdasarkan hal tersebut tidak ada hubungan antara tingkat kepatuhan minum obat antidiabetik oral terhadap kadar HbAlc.

Hasil penelitian ini sejalan dengan hasil penelitian Ulum, Kusnanto dan Widyawati (2014) yang berjudul kepatuhan medikasi penderita diabetes mellitus tipe 2 berdasarkan teori health belief model (HBM) di wilayah kerja Puskesmas Mulyorejo Surabaya pada 23 responden dianalisis menggunakan uji Chi Square dan Spearman's Rho . Faktor yang memiliki signifikan dengan kepatuhan medikasi penderita diabetes mellitus tipe 2 adalah faktor jenis kelamin, pendapatan, pengetahuan, persepsi keseriusan, persepsi manfaat, 
efikasi diri dan dukungan keluarga. Faktor yang tidak memiliki hubungan secara signifikan dengan kepatuhan medikasi penderita diabetes mellitus tipe 2 adalah faktor usia, suku, lama menderita sakit, persepsi kerentanan, persepsi hambatan. Faktor yang paling dominan adalah dengan kepatuhan medikasi penderita diabetes mellitus tipe 2 adalah persepsi keseriusan $(\mathrm{r}=0,565)$.

Fitriani (2011, h142) memaparkan kepercayaan kesehatan adalah persepsi seseorang tentang kerentanan dan kemujaraban pengobatan dapat mempengaruhi keputusan seseorang dalam perilaku kesehatan. Dimana kepercayaan kesehatan sendiri terdiri dari 6 komponen yaitu kerentanan, Keseriusan, manfaat, hambatan, isyarat untuk bertindak dan kepercayaan diri. Nies dan Mcewen (2015, h55) menjelaskan semakin besar resiko yang dirasakan maka semakin besar kemungkinan terlibat dalam perilaku untuk mengurangi resiko. Persepsi kerentanan sangat penting dalam memotivasi perilaku dimana persepsi kerentanan tinggi akan lebih memotivasi seseorang untuk melakukan suatu tindakan dibandingkan yang mempunyai persepsi kerentanan rendah. Perilaku kepatuhan minum obat penderita DM tipe 2 akan timbul jika seseorang merasa bahwa dirinya beresiko penyakitnya dapat menjadi lebih parah dan timbul komplikasi.

Hasil penelitian ini didominasi dengan kepercayaan kesehatan dengan persepsi kerentanan tinggi, hal ini kemungkinan disebabkan karena sebagian besar responden memperoleh banyak informasi dari tim kesehatan dan rerata menderita DM $<5$ tahun. Semakin lama menderita suatu penyakit maka semakin banyak pengalaman tentang penyakit dan ditafsirkan dalam bentuk persepsi. Perilaku kepatuhan minum obat penderita DM tipe 2 akan timbul jika seseorang merasa bahwa dirinya beresiko penyakitnya dapat menjadi lebih parah dan timbul komplikasi. Kerentanan merupakan kondisi yang subyektif sehingga penerimaan individu, khususnya penderita DM tipe 2 terhadap kerentanan timbulnya resiko komplikasi akibat tidak mematuhi sesuai anjuran dapat bervariasi.

Persepsi keseriusan merupakan kepercayaan individu tentang keseriusan atau keparahan penyakitnya (Priyoto, 2014, h136-138). Persepsi keseriusan yang dirasakan kemungkinan juga berbeda-beda setiap penderita DM tipe 2. Ketika seseorang merasa rentan beresiko bahwa penyakitnya dapat menjadi lebih parah dan timbul komplikasi maka hal tersebut mendorong dirinya untuk lebih serius minum obat. Kontrol kadar gula darah yang

Persepsi manfaat akan tinggi jika penderita DM tipe 2 menyadari manfaat yang besar dari kepatuhan minum obat terhadap penyakit yang diderita. Stanshope dan Lancaster (2016, h366-367) memaparkan persepsi seseorang tentang nilai atau kegunaan dari suatu perilaku baru dalam mengurangi resiko terkena penyakit. Respon dapat berbentuk respon pasif yaitu respon yang terjadi didalam diri manusia dan tidak secara langsung dapat terlihat oleh orang lain seperti berfikir dan pengetahuan. Keyakinan responden tentang manfaat yang diperoleh dengan mematuhi kepatuhan minum obat sesuai anjuran medis. Faktanya hasil penelitian ini banyak yang patuh dalam minum obat.

Persepsi Hambatan menganggap hambatan untuk patuh menjalankan kepatuhan minum obat. Glanz, Rimer dan Viswanath (2008, h48) memaparkan perubahan perilaku yang dapat terjadi dengan mudah bagi kebanyakan orang. Kepercayaan kesehatan kemungkinan individu melakukan tindakan pencegahan tergantung pada hasil dari 2 keyakinan atau penilaian kesehatan yaitu ancaman yang dirasakan dari sakit dan pertimbangan tentang keuntungan dan kerugian.

VPriyoto (2014, h136-138) menjelaskan isyarat untuk bertindak merupakan peristiwa-peristiwa, orang, atau hal-hal yang menggerakkan orang untuk mengubah perilaku mereka. Apabila individu bertindak untuk melawan atau mengobati penyakitnya, ada variabel kunci yang terlibat didalam tindakan tersebut yaitu kerentanan yang dirasakan terhadap suatu penyakit, keseriusan yang dirasakan, manfaat yang diterima dan hambatan yang dialami oleh seta hal-hal yang memotivasi hal tersebut. Tindakan seseorang dalam mencari pengobatan dan pencegahan penyakit dapat disebabkan karena keseriusan dari suatu penyakit yang dirasakan.

Bandura (2009, h185) memaparkan kepercayaan diri adalah keyakinan individu untuk melakukan sebuah tindakan kesehatan tertentu untuk mendapatkan hasil. Seseorang yang memiliki keyakinan akan kemampuan dirinya untuk menyelesaikan berbagai masalah maka ia akan memilih dan melakukan tindakan yang bermanfaat dan efektif untuk menyelesaikan masalahnya dengan baik.Kozier dan Erb's (2008,h304) kepatuhan minum obat merupakansejauh mana perilaku individu sesuai anjuran terapi atau kesehatan. Slamet (2007) perilaku kepatuhan sering diartikan sebagai usaha penderita untuk mengendalikan perilakunya, bahkan jika hal tersebut dapat menimbulkan resiko mengenai kesehatannya. American Diabetes Assosiation (ADA) telah mencatat perubahan perilaku yang diharapkan dari adanya pendidikan kesehatan yaitu: tingkat pengetahuan, sikap dan keyakinan, status psikologis, kondisi fisik, serta pola hidup sehat. Menurut peneliti penderita DM sangat rentan memiliki komplikasi maka diharuskan penderita harus patuh minum obat.

\section{Simpulan dan Saran}

Kepercayaan kesehatan pada penelitian ini minimal 65, maksimal 141 dan rata-rata 112.66 \pm 21.824 . Skor kepatuhan minum obat pada penelitian ini minimal 3 , maksimal 8 dan rata-rata $6.34 \pm 1.413$. Hasil uji pearson correlation pada responden nilai $\mathrm{p}$ value 0,000 atau nilai $\mathrm{p}$ value $<0,05$ yang berarti ada hubungan 
kepercayaan kesehatan dengan kepatuhan minum obat penderita diabetes mellitus tipe 2 di Puskesmas Karangnongko. Hubungan kepercayaan kesehatan dengan dengan kepatuhan minum obat menunjukkan korelasi positif yang sedang dengan nilai koefisien korelasi atau nilai $r=489$ yang berarti semakin besar kepercayaan kesehatan maka semakin tinggi kepatuhan minum obat pada penderita diabetes mellitus tipe 2 di Puskesmas Karangnongko.

\section{Daftar Pustaka}

Arikunto. (2013). Prosedur Penelitian suatu pendekatan praktik, Jakarta: Rineka Cipta

Bilous, R \& Donely , R. (2014). .Buku Pegangan Diabetes, Jakarta: Bumi Medika

Brunner \& suddarth . (2013). Keperawatan Medikal Bedah, Jakarta : EGC

Craven, Constance Hirnle \& Sahron Jensen. (2013). Fundamental of nursing human health and function,China: Wolter Kluwer Health/Lippincott Williams \& Wilkins

Delamater, A. M. (2006). Improving Patient Adherence. Clinical Diabetes, 24(2), 1-7

Dinas Kesehatan Kabupaten Klaten. (2016). Profil Kesehatan Kabupaten Klaten 2016.

Dinas Kesehatan Kabupaten Klaten. 2017. Profil Kesehatan Kabupaten Klaten 2017.

Dinas kesehatan provinsi jawa tengah (2013), profil kesehatan jawa tengah 2013. Semarang

Dinas Kesehatan Provinsi Jawa Tengah. (2016). Profil Kesehatan Provinsi Jawa Tengah 2016.

Eryna, L, P. (2016). Hubungan antara Latihan Jasmani dengan Kadar Glukosa Darah Penderita Diabetes. Departemen Epidemiologi Fakultas Kesehatan Masyarakat Universitas Airlangga.

Fitriani, (2011). Promosi Kesehatan. Yogyakarta : Graha Ilmu

Glanz, K., K. Rimer, K.,\& Viswanath, K. (2008). Health Behavior and Health Education Theory, Research, and Practice (4thed). United States

of America; Jossey Bass

Hasbi M. 2012. Analisis Faktor Yang Berhubungan Dengan Kepatuhan Penderita Diabetes Mellitus Dalam Melakukan Olahraga di Wilayah Kerja Puskesmas Praya Lombok Tengah. Tesis. Tidak Dipublikasikan

Hidayat, A. A. (2011). Metodologi Penelitian Kebidanan dan Teknik Analisis Data. Jakarta : Salemba Medika

Hurst, M. (2015) . Keperawatan Medikal Bedah, Jakarta : EGC

Kelana, D.K. (2011). Metodologi Penelitian Keperawatan, Jakarta: Trans Info Medika
Kemenkes , RI. (2017). Profil Kesehatan Indonesia Tahun 2016. Jakarta :Kementrian Kesehatan

Kozier \& erb's, (2008). Fundamentals of nursing concepts,process, and practice, United States of America: Pearson Education Inc

Kozier, Erb, Berman, Synder. (2010). Fundamental keperawatan konsep, proses \& praktik, Jakarta : Buku Kedokteran EGC

Lina ,E. P \& Nurhayati, T. (2017). Analisis Faktor Dominan Yang Mempengaruhi Kepatuhan Pasien DM Tipe 2 Dalam Melakukan Perawatan Kaki.

http://journal.unusa.ac.id/index.php/jhs/article/vi ewFile/377/353. ( diakses pada 28 Feruari 2018)

Lina, E, P dan Sholihatul, M. (2016). Faktor Risiko Komplikasi Kronis (Kaki Diabetik) dalam Diabetes Melitus Tipe 2. Fakultas Ilmu Kesehatan Universitas M uhammadiyah Ponorogo.

http://jurnal.unmuhjember.ac.id/index.php/TIJH S/article/view/382.(diakses pada 17 Februari 2018)

Maulana. (2009). Promosi Kesehatan, Jakarta: EGC

Morisky, D.E., DiMatteo, M.R.. (2011). Improving the measurment of self-reported medication nonadherence: Final response. Journal of Clinical Epidemiology, Vol. 64, p 258-263

Nies, M \& Mcewen, M. (2015). Community/public health nursing:promoting the health of populations, China: Elseivers Sunders

Niven, N . (2013). Psikologi Kesehatan. Edisi kedua, Jakarta : Penerbit Buku Kedokteran EGC

Notoadmojo, S. (2013). Ilmu Perilaku Kesehatan. Jakarta: Rineka Cipta

Notoatmodjo, S. (2012). Metodologi Penelitian Kesehatan, Jakarta : Rineka Cipta

Novita, N \& Franciska, Y. (2011). Promosi Kesehatan Dalam Pelayanan Kebidanan, Jakarta: Salemba Medika

Novyanda. H.,\& Hadiyanti W. (2017). Hubungan Penanganan Diabetes Militus : Edukasi Dan Diet Terhadap Komplikasi Pada Pasien DM Tipe 2 DiPoliklinik RSUP DR. Hasan Sadikin Bandung. http://journal.stikepppnijabar.ac.id/index.php/jkk/article/view/81. (diakes pada 28 Feb 2018)

Nursalam. (2011). Konsep Dan Penerapan Metodologi Penelitian Ilmu Keperawatan, Jakarta: Agung seto

Oktadiansyah. D., \& Yulia. (2014). Kepatuhan Minum Obat Diabetes Pada Pasien Diabetes Militus Tipe 2. http://www.digilib.ui.ac.id/naskahringkas/201609//S56361-Denny\%200ktadiansyah (diakses pada 28 Feb 2018) 
Padila, (2012). Keperawatan Medikal Bedah,Yogyakarta: Nuha medika

PERKENI. (2011). Konsensus Pengelolaan dan Pencegahan Diabetes Melitus Tipe Pencegahan Diabetes Melitus Tipe 2 di Indonesia 2011. Jakarta: PERKENI

Potter, P,. \& Perry, A. (2010). Fundamental Keperawatan (Edisi 7 Buku 1). Indonesia: Salemba Medika

Rasdianah, N., Martodiharjo., Andayani, T.,M \& Hakim, L.(2016) Gambaran kepatuhan pasien diabetes mellitus tipe 2 di Puskesmas Daerah Istimewa Yogyakarta. http://ijcp.or.id DOI :10.15416/ijcp.2016.5.4.249 (diakses pada 23 februari 2018)

Sastroasmoro, S. 2011 : Dasar-dasar Metodologi Penelitian Klinis. Jakarta : Sagung Seto

Smltzer, S.C \& Bare, B.G. (2012). Buku Ajar. Keperawatan Medikal Bedah Brunner and Suddarth.edisi 8 vol 3. Jakarta: Penerbit Buku EGC

Srikartika, V, M., Cahya, D.,A \& Hardiati. (2016). Analisis Faktor Yang Mempengaruhi Kepatuhan Penggunaan Obat Tipe 2. https://journal.ugm.ac.id/jmpf/article/view/29409 . (diakses pada 21 Maret 2018)

Stanhope, M \& Lancaster, J.(2016). Public health nursing: population centered health care in the community, America: Elseiver

Sugiyono, (2012). Statistika Untuk Penelitian, Bandung : Alfabeta

Sujarweni, W. (2014). Metodologi penelitian lengkap, praktis dan mudah dipahami, Yogyakarta :Pustaka baru press

Tarwoto (2012). keperawatan medikal bedah gangguan system endokrin, Jakarta: Trans Info Medika

Ulum, Z., Kusnanto \& Widyawati,I. Y., (2014). Kepatuhan Medikasi Penderita Diabetes Militus Tipe 2 Berdasarkan Teori Health Belief Model (HBM) Di Wilayah Kerja Puskesmas Mulyorejo Surabaya. http://journal.unair.ac.id/downloadfullpapers-cmsnjfccefe7eed2full.pdf. ( diakses pada 28 Feb 2018)

Utama, (2007). Penatalasanaan Diabetes Militus Terpadu, Jakarta : Balai Penerbit FKUI

Yasmara, D., Nursiswati \& Rosyidah, A. (2016). Rencana Asuhan Keperawatan Medikal Bedah, Jakarta: Penerbit Buku Kedokteran EGC

Yuliani, F, Oenzil,F \& Iryani,D . (2014). Hubungan berbagai faktor resiko terhadap kejadian penyakit jantung koroner pada penderita diabetes mellitus tipe 2. http://jurnal.fk.unand.ac.id (diakses pada 20 maret 2018) 